\title{
13. Coaching women and women coaching: pay differentials in the Title IX era Peter von Allmen*
}

\subsection{INTRODUCTION}

Title IX changed the landscape of intercollegiate sports for female highschool and college athletes. Prior to Title IX, colleges and universities averaged just 2.5 women's teams per institution, and total participation was fewer than 20,000 students. ${ }^{1}$ By 2010, schools fielded an average of 8.64 women's teams (over 9,000 teams in total), with over 1,500 additions in the last ten years alone. The number of female athletes now exceeds 180,000 (Acosta and Carpenter, 2010).

Opportunities to coach women's teams have grown with the number of female athletes. Ironically, the percentage of women employed as college coaches of women's teams has declined almost continuously since 1972. As Figure 13.1 shows, approximately 90 percent of women's teams were coached by women prior to Title IX. In the years immediately following

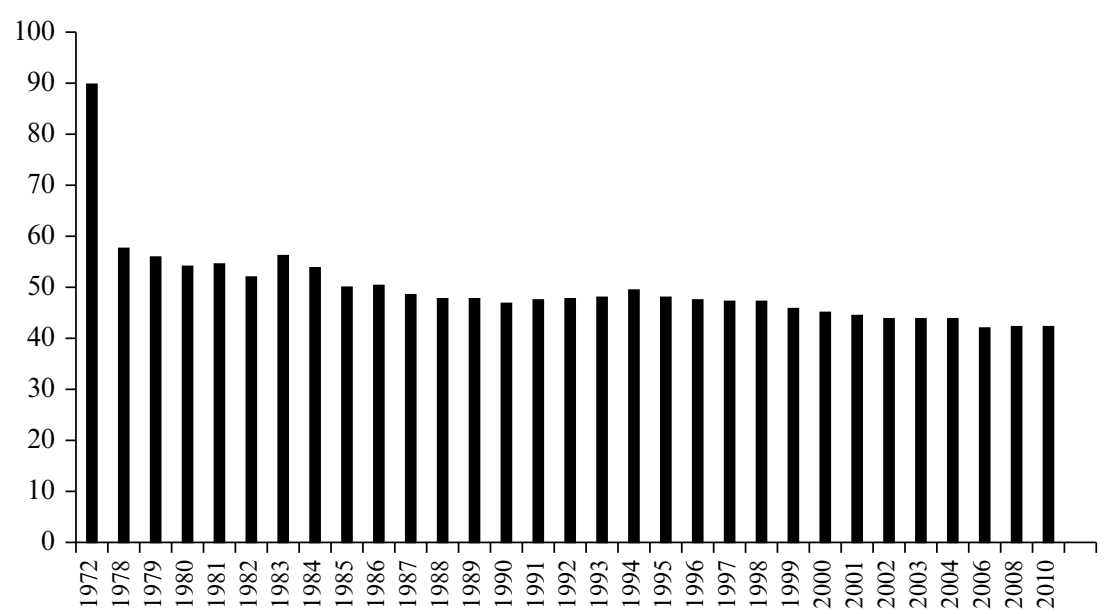

Source: Acosta and Carpenter (2010), at: http://www.acostacarpenter.org/2010pdf $\% 20$ combined $\% 20$ final.pdf.

Figure 13.1 Percentage of NCAA women's teams coached by women 
the implementation of Title IX, that figure fell to less than 60 percent. By 2010, just over 40 percent of women's teams were coached by women. In Division II, fewer than 35 percent of women's teams were coached by women.

Because the number of women's teams increased rapidly following the passage of Title IX, the initial increase in the number of teams coached by men may be simply a function of the supply of coaches with sufficient experience to coach at the college level. However, such reasoning cannot explain why the percentage of women coaches has continued to fall. Over 1,700 women's teams have been added since 1998, but the number of women coaches has increased by only about half that amount, and most of those gains were between 1998 and 2000. While 685 teams have been added since 2004, only 169 of them are coached by a woman (ibid.). Thus, the trend may well be worsening. In addition, average head and assistant coaching salaries at all levels, but particularly in Division I-A, are substantially higher for men's teams than for women's.

There are many possible explanations for the divergence between the number of women's teams and athletes and the number of women coaches. It may be the result of demand differences due to discrimination by employers (as investigated in Humphreys, 2000 and Brook and Foster, 2010). It may also be the result of employee discrimination by coworkers or role discrimination that discourages women from entering the coaching profession. Women's programs in general may also face differential treatment due to discrimination by employers. As a result, demand-side discrimination across gender lines may take the form of systematic differential treatment of either the women who coach (or would like to coach), women's programs, or both.

It could also be that the observed differences are not due to demand-side discrimination but to differences in supply-side factors, such as the difficulties in managing work-home life balance (as discussed in Fazioli, 2004 and Rhode and Walker, 2008). Coaching at the college level involves long and variable hours as well as significant travel. The challenges of balancing such a career with family have led even highly successful female coaches to quit. Gregory (2007) recounts the stories of coaches like Dena Evans, head cross-country coach at Stanford, and Karen Tessmer at Worcester State College (now Worcester State University) who often brought their infant children to practice with them. Despite winning a national championship, Evans decided to leave coaching. While these supply-side factors may play a role in observed gender differences in coaching, to fully address both supply- and demand-side considerations would require more space than a single chapter allows.

This chapter is one of the first to examine the dynamics of the labor 
market for coaches of women's teams at the college level from an economic perspective. The results of this study have important policy implications. If women are systematically discouraged from entering the coaching profession or treated differentially if they do, the National Collegiate Athletic Association (NCAA) and its member institutions should act to eliminate this problem. If women are discouraged at a societal level from coaching, the problem is no less troubling, but the solution is much more complex.

The issues surrounding women and coaching are multi-dimensional. To shed light on several of these dimensions, I analyze expenditures, performance, and salaries across team and coach gender lines. Section 13.2 looks across sports by gender. It compares coaching salaries at different divisions and subdivisions of the NCAA as well as operating expenses and total expenses for men's and women's teams without regard to the gender of the coach. Section 13.3 estimates the role of the coach's gender on the performance of top-ranked Division I softball teams. Section 13.4 estimates the relationship between the coach's gender on the salary of men's and women's golf coaches. Section 13.5 points out policy implications and offers suggestions for future research.

\subsection{RESOURCES DEVOTED TO SPORTS BY GENDER}

Changes in women's sports have been tracked extensively since the passage of Title IX, most notably through two comprehensive datasets. Acosta and Carpenter have detailed the progress of women's athletics for over 30 years in their annually updated 'Women in Intercollegiate Sport: A Longitudinal National Study'. This extraordinary work provides an excellent set of descriptive statistics that detail the changes in women's sports participation since Title IX. 'The Equity in Athletics Data Analysis Cutting Tool' (hereafter, Equity in Athletics Data), published by the Office of Post-Secondary Education (2011) of the US Department of Education, contains detailed information at the institution level on the number of coaches employed, revenues, and expenditures by institution by sport. In this section, I use the Equity in Athletics Data to analyze and compare the allocation of resources at various institutions and for selected sports.

\subsubsection{Coaching Salaries by Institution Type}

This subsection focuses on the question of equal pay for equal work. There are two questions of interest: do male and female coaches earn equal 
272 Handbook on the economics of women in sports

Table 13.1 2007 average head coaching salaries by institution type

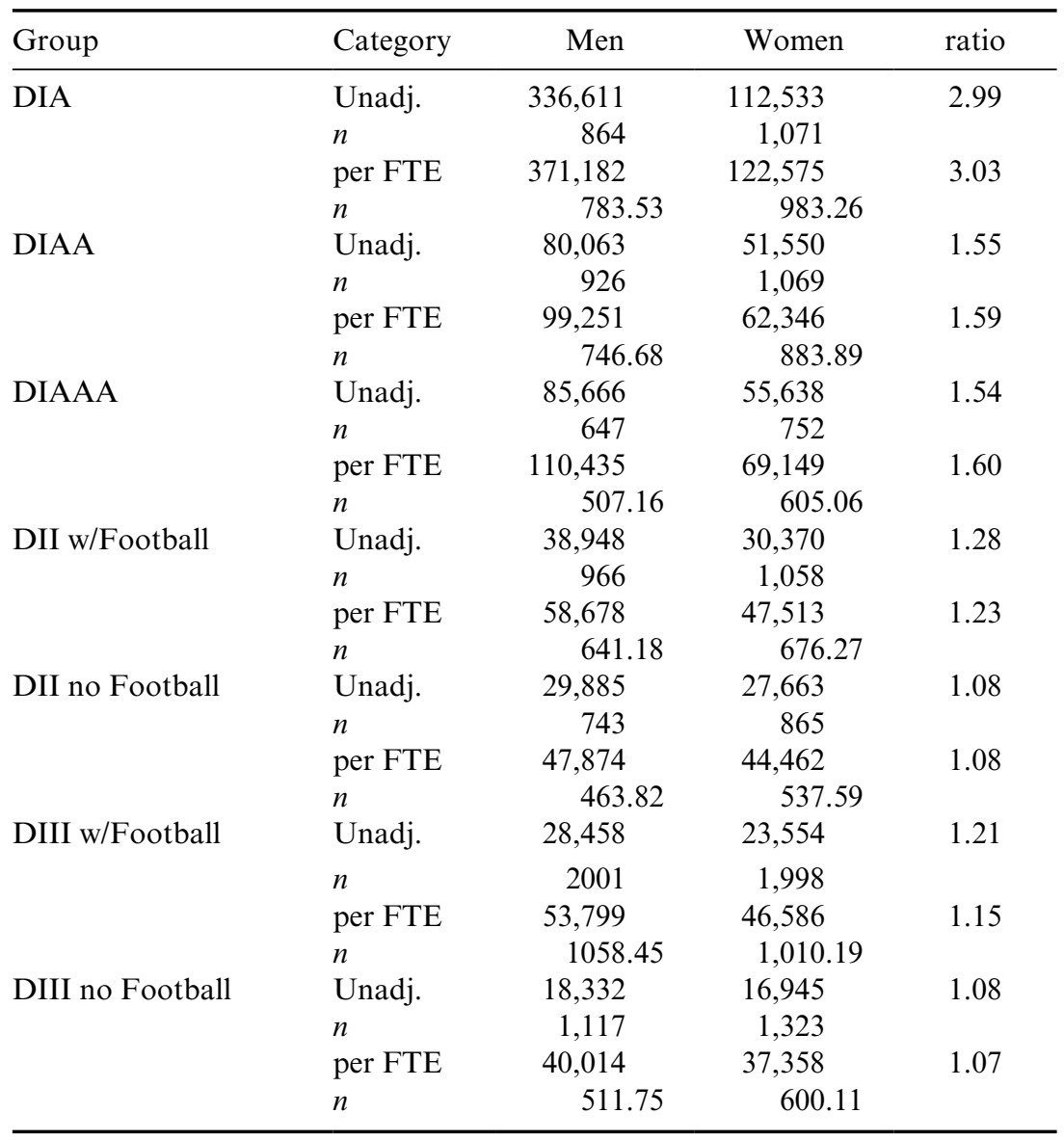

Source: 'The Equity in Athletics Data Analysis Cutting Tool', http://ope.ed.gov/athletics/.

salaries for equal work, and, do coaches of men's and women's teams, regardless of their gender, earn equal salaries?

Table 13.1 shows the average head coaching salaries for men's and women's teams by institution type for $2007 .^{2}$ In this case, we do not know the gender of the coach and so are comparing salaries across men's and women's teams. Because over 97 percent of men's teams are coached by men, the averages for men's teams correspond closely to salaries for male coaches. However, Figure 13.1 shows that only about 45 percent of women's teams are coached by women, making it impossible to draw 
conclusions from these data on the salaries of coaches by gender. (The Equity in Athletics Data do not provide the salaries of individual coaches.) I consider these questions in Section 13.4.

The NCAA divides Division I schools into several subcategories based on their football programs. The Football Bowl Subdivision (FBS, formerly Division IA) comprises 120 universities with very large football programs. These schools must offer at least 16 sports and must meet minimum attendance standards for football. The Football Championship Division (FCS, formerly known as Division IAA) consists of colleges and universities that sponsor Division I football at a lower level of commitment than FBS schools. FCS schools must offer 14 varsity sports rather than 16 and determine their football championship through a season-ending tournament rather than though bowl play and polling, as in the FBS. Division I (formerly Division IAAA) comprises schools that compete at the Division I level but do not sponsor football. ${ }^{3}$ To maintain consistency with the Equity in Athletics Data and avoid confusion with the generic use of the term 'Division' I, the former nomenclature for subdivisions is used throughout the chapter. Table 13.1 shows the unadjusted average salaries, the number of coaches in that subdivision, and the average annual salary adjusted to a full-time equivalent for each subdivision. Salaries shown do not include external income, such as income from endorsements. The means in the table are striking in two ways. First, the salaries of coaches of men's teams in Division IA are roughly three times those of coaches of women's teams. This differential is not surprising, given that average head coaching salary for Division IA football teams exceeded \$1 million for 2007 (AAUP, 2007-08 Table B). Second, salaries are much more equal at lower divisions, particularly in divisions that do not sponsor football, though the average salaries of the head coaches of men's teams are always higher.

Table 13.2 shows the same data as Table 13.1 but for assistant coaches. While the ratio of the salaries of the coaches of men's and women's teams is not as large as for head coaches, assistant coaches of men's teams in Division IA earn more than twice as much as women's assistant coaches. In all divisions that offer football except IAA, the unadjusted average for men's assistants is at least 50 percent more than the average for women's assistants. Although football may be driving this result, the ratio of men's teams' assistant salaries to women's teams' assistant salaries is 1.25 even in Division IAAA schools, which have no football program. ${ }^{4}$ Because many assistant coaches are part-time, it is important to consider the salary per full-time equivalent (per FTE). On this basis, assistants' salaries in men's sports are about 25 percent greater than assistants' salaries in women's sports in divisions below IA.

There are a number of possible reasons why these differences might 
274 Handbook on the economics of women in sports

Table 13.22007 average assistant coaching salaries by institution type

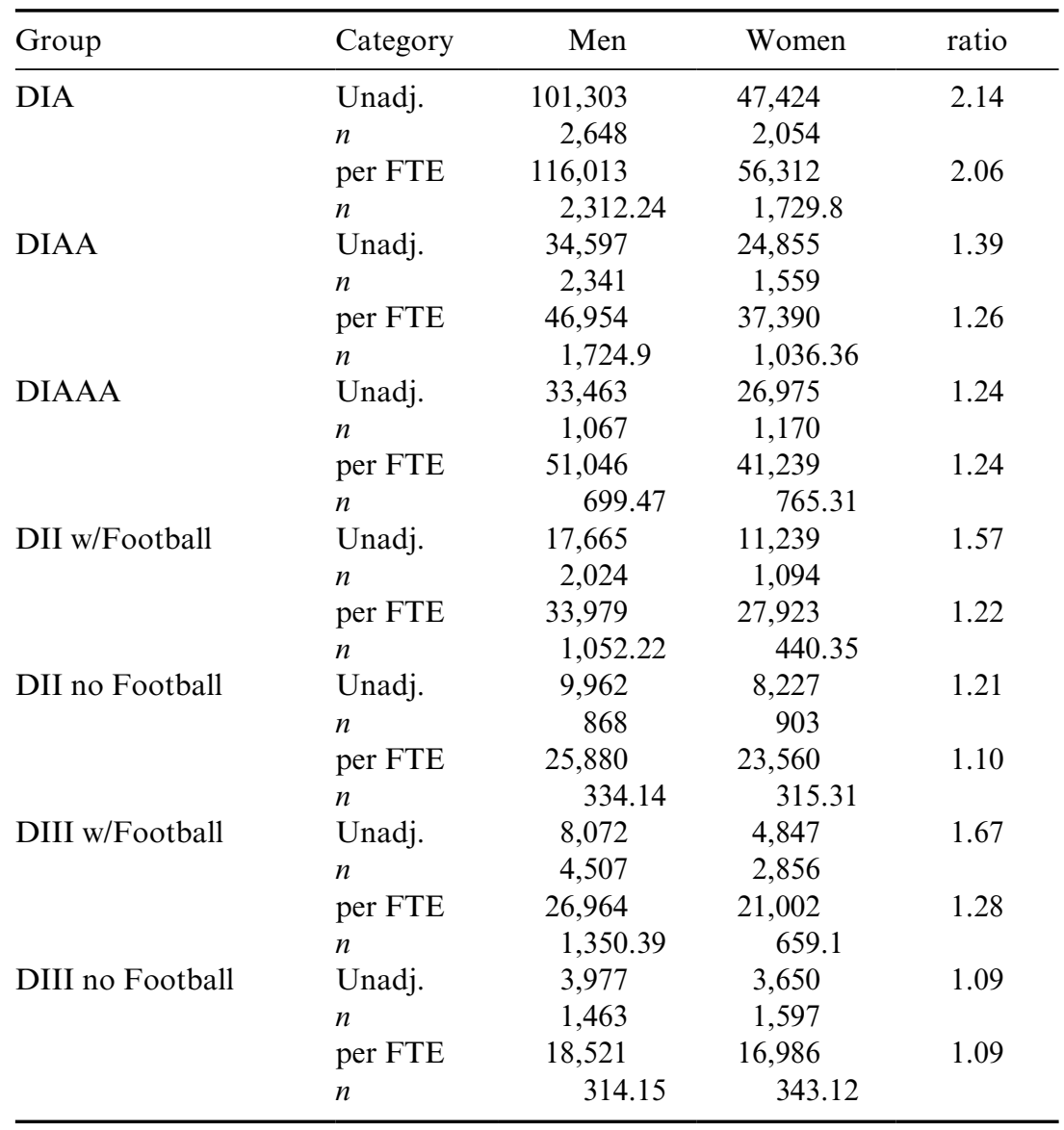

Source: 'The Equity in Athletics Data Analysis Cutting Tool', http://ope.ed.gov/athletics/.

exist. At a fundamental level, if the labor markets were otherwise competitive and characterized by a single salary, differences would be due to differential demand or supply. Alternatively, it could be that the supply of coaches for women's teams is greater than the supply of coaches for men's because women are systematically shut out of the men's market but not vice versa. If this is so, then the salaries of coaches of women's teams would be lower. In this case, discrimination in the form of unequal access to employment creates salary differences. We might also observe such a difference in supply if women did not want to coach men's teams, but 
the converse was not true. It that case, the difference in supply would not be due to discrimination. Given that less than half of women's teams are coached by women, it does appear that supply-side forces are responsible for some of the difference in salaries.

It could also be that salary differences are due to differences in demand. As noted above, this may imply that some form of discrimination is at work. In the absence of discrimination, demand is determined solely by marginal revenue product (MRP), which equals the extra output attributable to a worker (marginal product) times the additional revenue that a small increase in output brings (marginal revenue). Thus, salaries might differ due to differences in marginal revenue across men's and women's sports. While men's programs at Division I schools, particularly football and basketball programs, generate far greater revenue than women's programs, the difference in marginal revenue is much smaller at schools without these large revenue-producing sports, making revenue differences unlikely as a source of salary differences. I return to this discussion in Section 13.4. If differences in salaries are due instead to differences in marginal product, women's teams must be receiving lowerquality coaching than men's. This would easily explain salary differences if women were inferior coaches to men (given that virtually no women coach men's sports). I investigate this possibility further in Section 13.3.

The effects of either unequal access to work or unequal pay for equal work on both female student athletes and their coaches are far reaching. If colleges discriminate against women's teams by paying their coaches less, these jobs are less desirable than men's jobs, all else equal. As a result, male athletes may receive better coaching than women if the best coaches are attracted to and are hired for the highest-paying jobs. If female coaches are shut out of coaching men's teams but women's team salaries exceed the reservation salary for these women, female athletes may still receive high-quality coaching, but the coach suffers wage discrimination.

\subsubsection{Total Expenditures on Selected Sports by Division}

Many sports played at the collegiate level are essentially the same for men and women. For these sports, which include golf, tennis, soccer, baseball/softball, basketball, and volleyball, there is no reason to assume that the resources required to field a team of women are different from those required to field a team of men. ${ }^{5}$ Tables 13.3 and 13.4 break down operating expenses (that is, game-day expenses) and total expenses for these sports as well as for all sports and for football, where applicable, for all subdivisions within Division I. ${ }^{6}$ They also show the ratios of men's to women's team expenses. Table 13.3 also shows average expenditures per 


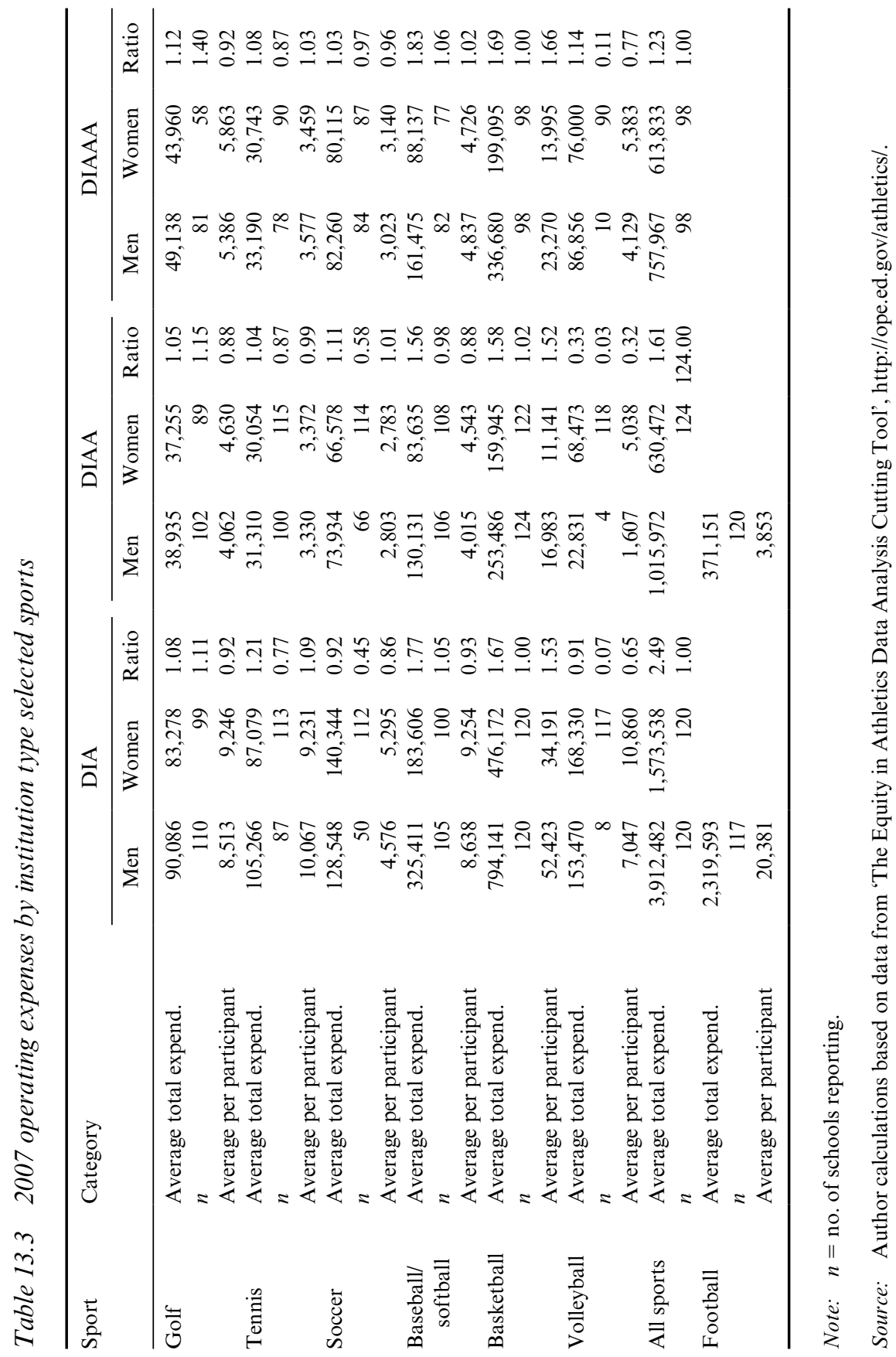




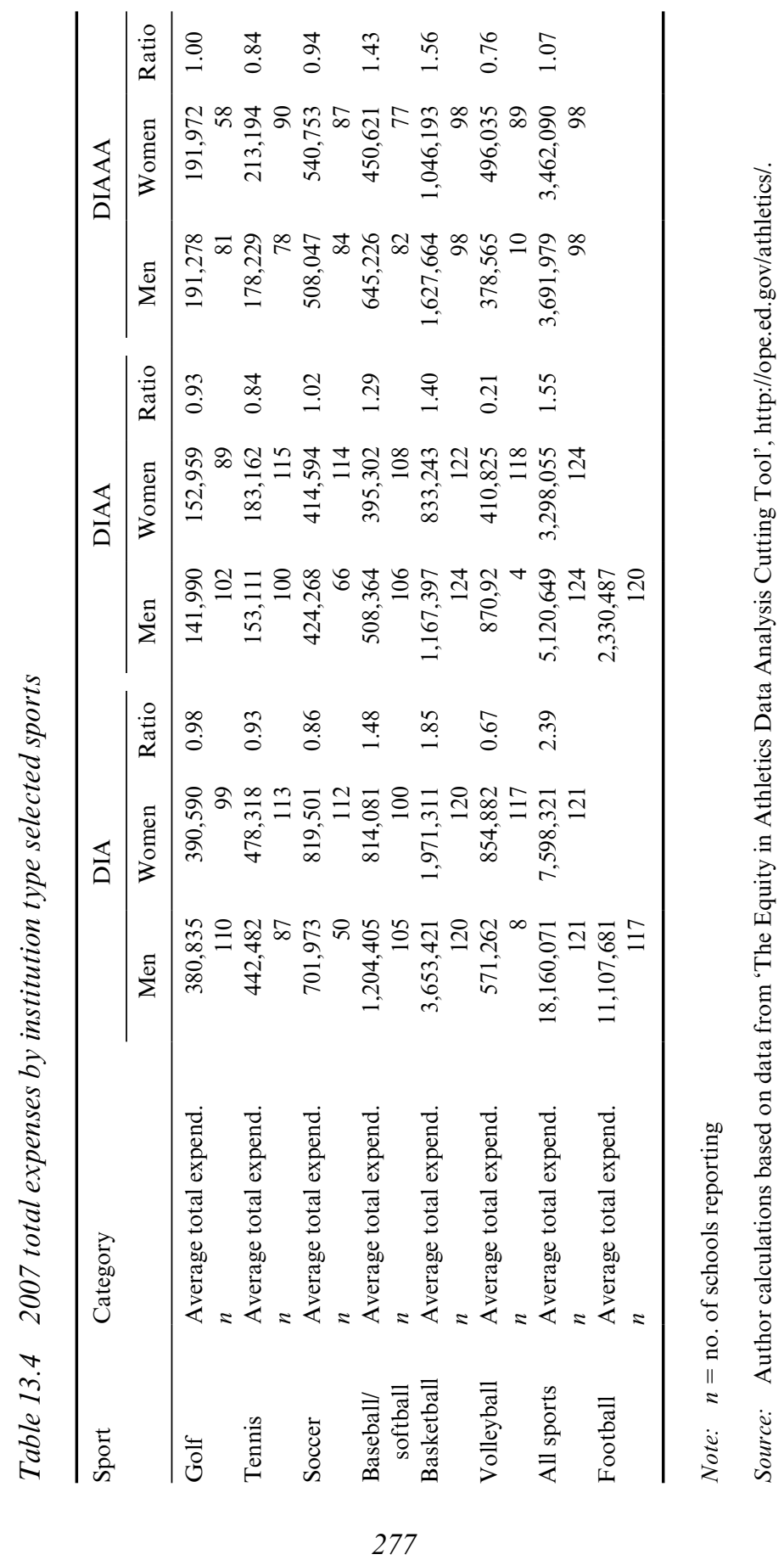


participant. All calculations are based on data from the Equity in Athletics Data for the 2006-07 season.

Table 13.3 shows that golf, tennis, and soccer have game-day expenses that are very similar across gender lines. At the participant level, expenses in golf, tennis, soccer, and baseball/softball are nearly all within 10 percent of one another, and expenses are more likely to be greater for women than for men. While the expense ratios for golf, tennis and soccer are quite similar, the ratios for basketball and volleyball are markedly different, though in opposite directions.

In basketball, operating expenses for men's teams are roughly 60 percent greater than for women's teams. Even at the participant level, the difference is greater than 50 percent at all levels. Such differences seem odd given that men's and women's basketball are identical games played on the same surface and that operating expenses do not include recruiting expenses, coaches' salaries, or athletically related student aid. One possible explanation is cost differences related to attendance, as men's basketball produces large revenues, in part due to high attendance levels, while women's games have much lower attendance. For example, average home attendance for men's basketball in 2007 was 5,327 per game while for women's games, it was just $1,586 .^{7}$ The differences in volleyball's operating expenses go in the opposite direction, particularly in Division IAA, where men's operating expenses are only about a third of those for the women's teams. I return to this point below.

Table 13.4 shows that across all sports, differences in total expenses are substantially greater in subdivisions with football, particularly Division IA, where the ratio of expenditures on men's sports to women's sports is 2.39. By contrast, in Division IAAA, that same ratio is just 1.07. At the individual sport level, the ratio of total expenses for men and women is again very close to 1.0 for golf, tennis, and soccer, and for most of these sports, men's total expenses are less than women's. This is particularly true again for volleyball, where the expenses for women are much greater than those for men. It is notable that none of these sports is a 'revenue sport' (that is, not basketball or football) for either gender.

There are two possible explanations for these systematic differences. First, women's teams might receive more non-scholarship resources than men's in the form of better equipment, better facilities, higher coaching salaries, or any other category of expenses included in the total. Second, there might be significant differences in scholarships. For example, in women's volleyball, Division I institutions may offer up to 12 scholarships (which are not divisible across athletes). Men's volleyball teams, however, are allotted only 4.5 scholarships (which may be given as partial scholarships among more than five players). The Equity in Athletics Data do 
not include scholarships or aid broken down by sport. At the aggregate level (across all sports), they report that average aid to men exceeds aid to women by approximately $\$ 900,000$ and $\$ 350,000$, respectively, in Division IA and IAA, but Division IAAA schools, which do not offer football, offer women $\$ 360,000$ more in aid than they offer men. Thus, in Divisions IA and IAA, the large number of football scholarships clearly masks differences in other sports.

The total expense ratios are quite different for basketball. In all three subdivisions of Division I, men's expenses exceed women's by at least 40 percent. Basketball differs from the other sports in Table 13.4 in that men's Division I basketball is a large revenue-producing sport. Thus, the best men's coaches command extraordinary salaries for reasons that do not hinge on discrimination.

In summary, while men's and women's teams of like sports may receive substantially different resources, the sources of these differences are difficult to pinpoint, particularly in Divisions IA and IAA (though football and basketball coaching salaries at major programs are responsible for some of those differences). A closer look at specific non-revenue sports and sports at institutions without football reveals that funding is much more equal (particularly in the case of operating expenses) and that funding for women is often as much as or greater than funding for men.

\subsection{COACHING PERFORMANCE BY GENDER IN SOFTBALL}

As Figure 13.1 showed, more than half of all women's teams are now coached by men. Three factors might lead to lower representation of women in the coaching ranks. The first is a lack of desire by women to coach (as noted in the Introduction), which affects the supply side of the market. Second, discrimination against women could affect the demand side of the market. Finally, it could be that men are systematically more productive than women. In this case, there would be differences in demand across gender, but not because of discrimination. This section investigates productivity differences as a potential source of differential demand.

Casual observation indicates that women are at least as likely to coach highly successful women's athletic teams as men are. Women hold many head coaching positions at top-ranked programs in softball and in women's basketball and soccer. Based on end-of-season rankings for 2006-07, 60 percent of women's basketball teams (AP poll) teams, 32 percent of women's soccer teams (Soccer America ranking), and 60 percent of softball teams (RPI ranking) in the top 25 had female coaches. Taken 
together, these 75 top-ranked teams were just as likely to be coached by a woman as by a man. ${ }^{8}$

To investigate the success of female coaches more thoroughly, I examine a single sport in greater detail. The analysis below focuses on Division I softball. The NCAA publishes team rankings using an index known as RPI (rating percentage index), which is calculated based on team performance and strength of schedule (the opponent's winning percentage and the winning percentage of the opponent's opponents). This index is available for all Division I teams. While other ranking systems exist, they are not conducive to econometric study, as polls, such as USA Softball, do not extend beyond the top 25 teams. The model below includes the top 100 teams in the final 2007 rankings. Of these programs, 71 percent are coached by women.

If women and men are equally skilled at coaching, we should not observe a systematic relationship between the gender of the coach and the RPI ranking of the team. To test this hypothesis, it is important to control for other factors that influence team ranking. One such factor is program expenditures because team performance is likely to be influenced by program expenses relative to competing programs. To control for this, I construct the ratio of expenditures of each program to the expenses of all programs in the sample (SHAREEXP). The expected sign of the coefficient for this variable is negative in that greater expenses relative to opponents should lead to a higher ranking (that is, a lowerranking number).

In addition to controlling for expenses, a program's history of success will likely influence its ability to attract top recruits. Thus, the model should control for program reputation. To do so, I construct a variable (WS10) equal to the number of World Series appearances over the 10-year period, 1996-2005. ${ }^{9}$ The expected sign of this coefficient is also negative, as a better program reputation should lead to higher ranking.

Given that strength of schedule is an important determinant of RPI, the model also includes a dummy variable for the $P A C-10$, which is the dominant conference in women's softball. Of the 74 World Series appearances by teams included in WS10, 37 are by schools in the $P A C-10$. No other conference has more than 10 appearances over the same period.

Finally, the model includes a dummy variable for the gender of the coach (male coach $=0$ ). As noted above, if men and women are equally skilled at coaching, gender should not be a significant determinant of team rank. The complete specification is shown in equation (13.1). Results appear in Table 13.5.

$$
R P I=f(S H A R E E X P, W S 10, P A C-10, \text { GENDER }) .
$$


Table 13.5 Coaching productivity in women's softball

\begin{tabular}{lrrrr}
\hline Variable & Coefficient & Std err. & $t$-value & $P>|t|$ \\
\hline Constant & 92.01 & 7.91 & 11.63 & 0.000 \\
GENDER & 4.14 & 5.17 & 0.80 & 0.425 \\
SHAREEXP & -3933.81 & 650.44 & -6.05 & 0.000 \\
WS 10 & -3.11 & 1.58 & -1.97 & 0.052 \\
$P A C-10$ & -9.56 & 10.78 & -0.89 & 0.378 \\
Adj. $R^{2}=0.41$ & & & & \\
\hline
\end{tabular}

Note: Dependent variable is women's softball rank $(n=100)$.

The results for individual coefficients reveal much about successful softball teams. The model explains the data rather well, with an adjusted- $R^{2}$ of 0.41 . Relative expenditure by team is strongly significant in the expected direction. Teams that spend more achieve a higher end-of-season rank. In addition, program reputation, as measured by WS10, is significant in the expected direction. $P A C-10$ is not significant, though this may be due to its relatively strong correlation with $\operatorname{WS10}(r=0.60)$. Most importantly, the coefficient on the gender of the coach is not significantly different from zero, indicating that male and female softball coaches do not perform differently. This result provides substantial evidence that female coaches have skills equal to those of their male counterparts.

\subsection{THE DETERMINANTS OF COACHING SALARIES}

Because data on athletic performance are so widely available, studies of the salaries of professional athletes are very common. Research on coaching salaries is much less common. Two important examples are the work of Humphreys (2000) and Brook and Foster (2010), both of whom studied the salaries of college basketball coaches.

Using data from 1990 to 1991, Humphreys finds that coaches of men's teams earn substantially more than coaches of women's teams (regardless of the gender of the women's team coach). Among women's teams, the median salary of female coaches is about 9 percent more than that of male coaches. He estimates several salary models for different samples and specifications. In specifications that include only women's teams, Humphreys finds that female coaches earn significantly more than male coaches do, even after controlling for other factors, though the margin 
falls to approximately 7 percent. He also finds that career-winning percentage is positively related to salary, as are basketball revenue and the size of the institution.

Humphreys shows that if one considers only the head coaches of women's teams, as the percentage of other coaches in the program that are women increases, the salaries of women's basketball coaches rise. Using a combined sample that includes both men's and women's programs, he finds that women's head coaching salaries are about half those of men even after controlling for institutional factors (including revenue). He concludes that the large gender gap may be attributable to one of three forces: the differential effects of program prestige on athletic director decisions, possible tastes for discrimination by athletic directors or consumers, and a greater ability of men's head coaches to capture monopoly rents.

Brook and Foster also analyze Division I men's and women's basketball. Their data and approach differ from Humphreys' in that they use total program compensation (that is, head and assistant coaches), actual rather than estimated revenues, and more recent data than Humphreys. They conclude that differences in wages across team-gender lines are most likely due to revenue differences - that is, that coaching men's and women's teams are two distinct labor markets.

\subsubsection{Golf Salary Model}

To build on the above work, this subsection considers coaching salaries in a very different sport. Like basketball, golf is essentially the same game for men and women. Unlike basketball, neither men's nor women's golf is a large revenue-producing sport. Thus, it provides a very different perspective on differences across team-gender lines. As Brook and Foster (2010) report, in Stanley v. University of Southern California, the Court of Appeals rejected the claim of gender discrimination because men's basketball revenues were 90 times those of women's. In golf, no such dramatic difference exists. According to Equity in Athletics Data, for the 96 Division IA schools that offer both men's and women's golf, almost half of golf-related revenues come from women's teams. In Division IA, men's teams average under $\$ 25,000$ more in revenue than women's teams. This small difference in revenue makes it more difficult to explain why data published in Golfweek show that coaches of men's teams earned about \$72,200 in 2006-07, while coaches of women's teams averaged just $\$ 61,100$. It seems clear that such differences are not due to inferior coaching by women, as 18 of the top 25 programs in the sample are coached by women.

To determine what factors determine the salaries of golf coaches, I estimate separate equations for men's and women's teams. For women's 
teams, a key variable of interest is the gender of the coach (GENDER). Of the 76 teams in the women's sample, 55 were coached by women and 21 were coached by men. This variable is absent from the men's specification, as all men's teams had male coaches. Other variables are measures of experience and productivity: the tenure of the coach (TENURE), tenure squared (TENURESQ), and the number of conference championships won by that coach $(C O N F C H)$. I also include a dummy variable equal to 1 if the individual was coach of both the men's and women's teams $(M A N D W)$. Total athletic revenue at the institution (ATHREV) and a dummy variable equal to 1 if the school had a football program (FOOTBALL) measure the athletic program's resources and prestige. To control for the overall emphasis on sports of a given gender at each institution, EXPRATIOFT is the share of total athletic expenses devoted to women's programs and EXPRATIOMT is the share of total athletic expenses devoted to men's programs. For the women's programs, one additional independent variable captures the gender climate at the institutions (following Humphreys, 2000): the percentage of coaches at the school that are women (PCTFEMALE). Total enrollment at the institution (TOTPOP) controls for the effects of school size. Consistent with standard practice in salary estimation, the dependent variable is the natural logarithm of salary ( $L N S A L A R Y$ ). Thus the coefficients approximate the percentage change in salary given a one-unit change in the independent variable. The full specification of the men's salary equation is shown in equation (13.2). The women's salary equation is shown in equation (13.3).

$$
\begin{aligned}
\text { LNSALAR } Y_{M}= & f(T O T P O P, \text { ATHREV, EXPRATIOMT, FOOTBALL, } \\
& \text { TENURE, TENURESQ, CONFCH, } \\
& \text { GOLFWEEKRANK, MANDW }
\end{aligned}
$$

$$
\begin{aligned}
\text { LNSALARY } Y_{W}= & f(T O T P O P, \text { ATHREV, EXPRATIOFT, FOOTBALL, } \\
& \text { PCTFEMALE, GENDER, TENURE, TENURESQ, } \\
& \text { CONFCH, CONFCH, GOLFWEEKRANK, } \\
& \text { MANDW }
\end{aligned}
$$

The data for coaching salaries come from Golfweek magazine, which published the head coach salaries by institution of the top 100 men's and women's teams for that year (less a few missing observations for which they did not have data). ${ }^{10}$ Salaries represent base pay only and do not include additional income earned from camps, bonuses or equipment contracts. As such, they do not represent the full returns to productivity, but they still provide useful information on differences across team and gender lines. Additional data on individual coaches and the percentage of teams 
Handbook on the economics of women in sports

Table 13.6 Wage determination in NCAA men's golf coaches, 2006-07

\begin{tabular}{lcc}
\hline Dependent variable is lnsalary & $N=74$ & \\
\hline Variable & Model 1 & Model 2 \\
\hline TOTPOP & $8.94 \mathrm{e}-06^{* *}$ & $8.83 \mathrm{e}-06$ \\
& $(2.03)$ & $(1.94)$ \\
ATHREV & $-2.14 \mathrm{e}-08$ & $-2.43 \mathrm{e}-08$ \\
& $(-0.88)$ & $(-0.97)$ \\
EXPRATIOMT & 0.606 & 0.499 \\
& $(1.58)$ & $(1.10)$ \\
FOOTBALL & 0.141 & 0.146 \\
& $(1.01)$ & $(0.99)$ \\
TENURE & - & 0.005 \\
& - & $(0.34)$ \\
TENURESQ & - & -0.00008 \\
& - & $(-0.17)$ \\
CONFCH & 0.019 & 0.0145 \\
& $(1.73)^{* * *}$ & $(1.07)$ \\
GOLFWEEKRANK & $-0.0005^{*}$ & $-0.0049^{*}$ \\
& $(-3.84)$ & $(-3.57)$ \\
MANDW & - & -0.0937 \\
& - & $(-0.52)$ \\
Constant & $10.643^{*}$ & $10.687^{*}$ \\
& $(41.25)$ & $(33.20)$ \\
$R$-squared & 0.416 & 0.422 \\
Adj $R$-sq. & 0.364 & 0.341 \\
\hline
\end{tabular}

Note: $t$-values in parentheses. * indicates significance at $1 \%$ level; ** indicates significance at $5 \%$ level; *** indicates significance at $10 \%$ level.

coached by women are from institution and conference websites. Revenue and expenses data are from Equity in Athletics Data and are recorded in thousands of dollars. The final sample includes 76 women's team coaches and 74 men's team coaches, all from Division I.

The results for the men's equation are in Table 13.6. The results for women's teams are in Table 13.7. The original specification is shown as Model 2 in both tables. In each case, variables that had virtually no influence on the dependent variable were dropped to arrive at the final specification, which is shown as Model 1 in both tables. For men's teams, the primary drivers of salaries are the size of the institution and the performance of the team as measured by rank. Interestingly, the other experience measures, the productivity variables (that is, TENURE and CONFCH), and the presence of a football team do not impact salaries. The overall 
Table 13.7 Wage determination in NCAA women's golf coaches, 2006-07

\begin{tabular}{|c|c|c|}
\hline \multicolumn{3}{|c|}{ Dependent variable is lnsalary $\quad N=76$} \\
\hline Variable & Model 1 & Model 2 \\
\hline \multirow[t]{2}{*}{ TOTALPOP } & - & $7.30 \mathrm{e}-08$ \\
\hline & - & $(0.02)$ \\
\hline \multirow[t]{2}{*}{ EXPRATIOFT } & $0.455^{* *}$ & $0.448 * *$ \\
\hline & $(2.04)$ & $(1.86)$ \\
\hline \multirow[t]{2}{*}{ ATHREV } & $3.28 \mathrm{e}-06^{*}$ & $3.25 \mathrm{e}-06^{* *}$ \\
\hline & $(2.75)$ & $(2.57)$ \\
\hline \multirow[t]{2}{*}{ FOOTBALL } & $0.180 * *$ & $0.176^{* * *}$ \\
\hline & 2.13 & $(2.07)$ \\
\hline \multirow[t]{2}{*}{ PCTFEMALE } & - & 0.032 \\
\hline & - & $(0.17)$ \\
\hline \multirow[t]{2}{*}{ GENDER } & $0.130 * *$ & $0.128 * * *$ \\
\hline & 1.96 & $(1.74)$ \\
\hline \multirow[t]{2}{*}{ TENURE } & $-0.029 * * *$ & $-0.029 * * *$ \\
\hline & $(-1.88)$ & $(-1.86)$ \\
\hline \multirow[t]{2}{*}{ TENURESQ } & $0.001 * *$ & $0014 * *$ \\
\hline & $(2.26)$ & $(2.10)$ \\
\hline \multirow[t]{2}{*}{ CONFCH } & - & -0.0009 \\
\hline & - & $(0.08)$ \\
\hline \multirow[t]{2}{*}{$M A N D W$} & 0.116 & 0.117 \\
\hline & $(1.36)$ & $(1.38)$ \\
\hline \multirow[t]{2}{*}{ GOLFWEEKRANK } & $-0.008^{*}$ & $-0.008^{*}$ \\
\hline & $(-6.42)$ & $(-6.36)$ \\
\hline \multirow[t]{2}{*}{ Constant } & $10.90^{*}$ & $10.90 *$ \\
\hline & $(95.51)$ & $(73.45)$ \\
\hline$R$-squared & 0.701 & 0.701 \\
\hline Root MSE & 0.199 & 0.203 \\
\hline
\end{tabular}

Note: $t$-values in parentheses. * indicates significance at $1 \%$ level; ** indicates significance at $5 \%$ level; *** indicates significance at $10 \%$ level. Estimated using robust standard errors.

fit of the equation is good, with an adjusted $R^{2}$ of about 0.36 in the final specification.

For women's teams (shown in Table 13.7), the overall performance of the final specification is even better, as the $R^{2}$ is 0.70 . Greater total athletic revenue at the institution increases coaches' salaries. All else equal, female coaches earn about 13 percent more than male coaches. Increases in expenditures on women's sports (EXPRATIOFT) result in increased wages for coaches. In contrast to the results for men's teams, the existence of a football program increases salaries for coaches of women's teams 
- a result that appears to run counter to the often-stated argument that Division I football teams do not subsidize other programs. It is possible, however, that FOOTBALL is a proxy for an overall commitment to athletics at those institutions that pay higher salaries to coaches of women's teams. The coefficient for PCTFEMALE is not significant. This result, related to the gender balance of the overall athletic department, contradicts Humphreys, who found evidence that having more female coaches on staff increased female coaches' salaries. The remaining results are similar to those of men, in that tenure and the number of conference championships do not appear to impact salary, nor does having joint responsibility for both men's and women's teams (though this result should be interpreted with caution, as the incidence of joint coaching responsibilities was only true for a small number of coaches in the sample). Finally, the rank of the program strongly impacts salaries in the expected direction, indicating that coaches are compensated for current team quality.

\subsection{CONCLUSION}

This chapter contributes to research on how colleges treat women's teams and female coaches by evaluating salaries and expenses at an aggregate level and productivity and wages at an individual sport level. Aggregate data indicate that coaches of women's programs earn less than coaches of men's programs at both the head and assistant coach levels. These differences are particularly pronounced at larger institutions, and data here generally reinforce the often-cited notion that large, revenue-producing sports drive much of this difference. Resources at the individual sport level tend to be distributed much more equally. With the exception of basketball and baseball/softball, the operating expenses and total expenses for sports played by both men and women are similar, and the resources of women's programs frequently exceed those of men's programs. Thus, a familiar theme emerges - the existence of large football programs creates a large disparity in resources.

Evidence from women's softball indicates that women are no less skilled than men at coaching. At the individual program level, casual observation shows that analysis of Division I softball programs shows that women perform just as well as their male counterparts. From a policy perspective, it is important for athletic directors to be aware of this result. If women are discriminated against in the form of unequal access to these positions due to perceived differences in quality, these results can help to educate institutions regarding their misperceptions.

The analysis of salaries for men's and women's golf - a non-revenue 
sport - indicate that female coaches earn more than male coaches, even after adjusting for the performance of the team. In women's programs, there are increasing returns to tenure, though the benefit of experience takes many years to accrue. In general, given the similarities in responsibilities, differences in the base salaries in men's team and women's team labor markets are difficult to explain and so represent a fruitful opportunity for further research.

Taken together, the results indicate that, at the aggregate level, large athletics programs still have significant work to do to equalize athletics expenditures across gender lines. Results from the softball and golf analyses indicate that there are also supply-side issues at work. Women should be encouraged to coach, and athletic directors should provide the opportunity to do so. Based on the results here, women who choose coaching as a career perform just as well as men. Given that women coach less than half the women's teams - and that the percentage is falling - colleges should do more to encourage coaching as a career among women. Institutions should also develop programs to help coaches overcome the kinds of work-life balance barriers identified in Rhode and Walker (2008) and Fazioli (2004). While institutions will not be able to eliminate the stresses of the home-work balance problem for coaches - male or female additional resources aimed at easing this constraint would likely be well spent.

\section{NOTES}

* A previous version of this chapter was presented at the 2011 Meetings of the Western Economic Association, San Diego, California. The author gratefully acknowledges helpful comments from David Berri, the participants at the conference session, and the editors of this volume.

1. For an extended treatment of Title IX, see Chapter 9 of this volume.

2. To maintain consistency across sections of the chapter, data in all tables is from the 2006-07 academic years. Salaries represent '(A)ll wages and bonuses the institution pays a coach as compensation attributable to coaching', 'Equity in Athletics Data Analysis Cutting Tool, Glossary of Terms' at: http://ope.ed.gov/athletics/glossaryPopup.aspx?idlink $=16$ (accessed November 23, 2011).

3. For additional details on the breakdown of the subdivisions of Division I, see 'Differences Among the Three Divisions: Division I', at: http://www.ncaa.org/wps/ $\mathrm{wcm} /$ connect/public/ncaa/about + the + ncaa/who + we + are/differences + among + the + divisions/division $+\mathrm{i} /$ about + division $+\mathrm{i}$ (accessed November 23, 2011).

4. A few Division IAAA schools do offer football, though they play that sport in lower divisions.

5. Baseball and softball are somewhat of an anomaly in that, although they are similar games, men's rosters are much larger than women's on average due to differences in pitching staff size. According to the Equity in Athletics Data, men's Division IA baseball rosters average over 37 players, while softball rosters in the same division average just over 20 players. 
6. Operating expenses include '(A)ll expenses an institution incurs attributable to home, away, and neutral-site intercollegiate athletic contests (commonly known as gameday expenses), for (A) Lodging, meals, transportation, uniforms, and equipment for coaches, team members, support staff (including, but not limited to team managers and trainers), and others; and (B) Officials'. Total expenses include '(A)ll expenses attributable to intercollegiate athletic activities. This includes appearance guarantees and options, athletically related student aid, contract services, equipment, fundraising activities, operating expenses, promotional activities, recruiting expenses, salaries and benefits, supplies, travel, and any other expenses attributable to intercollegiate athletic activities', Equity in Athletics Glossary, at: http://ope.ed.gov/athletics/glossaryPopup. aspx (accessed June 7, 2011).

7. Sources: NCAA.org. 'Men's 2007 Basketball Attendance' at: http://fs.ncaa.org/Docs/ stats/m_basketball_RB/Reports/attend/2007.pdf and NCAA.org. 'Women's 2007 Basketball Attendance', at: http://fs.ncaa.org/Docs/stats/w_basketball_RB/reports/ Attend/07att.pdf (accessed December 1, 2011).

8. Rankings are from Soccer America's College Soccer Reporter. 'Soccer America Women's Top 25: Final Rankings', at: http://www.socceramerica.com/article/1614/5soccer-america-womens-top-25-final-rankings.html; NCAA.org. '2007 Women's Softball RPI', at: http://web1.ncaa.org/app_data/weeklyrpi/2007WSBrpi1.html; and ESPN Women's Basketball, '2007 NCAA Women's Basketball Rankings Postseason', at: http://espn.go.com/womens-college-basketball/rankings/_year/2007. Data on gender of head coaches are from the individual institution websites. Data on the gender of the coaches are from each institution's website.

9. Eight teams advance to the College World Series each year. The 1996-2005 period was chosen to capture the recent history of the program. The year 2006 was omitted to reduce undue emphasis on current player quality (that is 2007 ranking is likely to be strongly affected by players already at the institution in 2006.)

10. Golfweek ('College Coaching Salaries: Who Makes What?', 2009) indicated that most salaries were from 2006-07 but does not specifically identify the year for every institution. In a few cases, salaries were reported from 2007-08 (and were eliminated from the sample). In order to test the robustness of the estimates, all observations for which the coach had less than one full year of tenure prior to 2006-07 were dropped from both the men's and women's equations, and the final specification (model 1) was re-estimated (results not shown). The resulting sample sizes were 71 for women and 69 for men. The results were very similar with an average change in statistically significant coefficients in the men's equation of 8.3 percent and 3.5 percent in the women's equation. Particularly in the women's equation, many of the key coefficients remained virtually constant. As a result, the results for the full sample are shown in Tables 13.6 and 13.7 .

\section{REFERENCES}

Acosta, R. Vivian and Linda Jean Carpenter (2010), 'Women in Intercollegiate Sport: A Longitudinal, National Study, Thirty Year Update', online at: www.acostacarpenter.org (accessed May 21, 2011).

American Association of University Professors (AAUP) (2007-08), 'Report on the Economic Status of the Profession', online at: http://www.aaup.org/AAUP/comm/rep/Z/ ecstatreport2007-08 (accessed April 19, 2011).

Brook, Stacey L. and Sarah Foster (2010), 'Does Gender Affect Compensation Among NCAA Basketball Coaches?', International Journal of Sport Finance, 5(2), May: 96-106.

'College Coaching Salaries: Who Makes What?' (2009), Golfweek, November 24. Original publication date: September 8, 2007. online at: http://www.golfweek.com/news/2009/ nov/24/look-who-makes-what-college-coaching/ (accessed June 21, 2011). 
ESPN Women's Basketball, '2007 NCAA Women's Basketball Rankings - Postseason', online at: http://espn.go.com/womens-college-basketball/rankings/_/year/2007 (accessed December 1, 2011).

Fazioli, Jennifer K. (2004), 'The Advancement of Female Coaches in Intercollegiate Athletics', Background paper for the Coaching and Gender Equity project, April.

Gregory, Sean (2007), 'Where are the Women Coaches?', Time, August 16.

Humphreys, Brad R (2000), 'Equal Pay on the Hardwood: The Earnings Gap Between Male and Female NCAA Division I Basketball Coaches', Journal of Sports Economics, 1(3), May: 299-307.

NCAA.org, 'Men's 2007 Basketball Attendance', online at: http://fs.ncaa.org/Docs/stats/m basketball_RB/Reports/attend/2007.pdf (accessed December 1, 2011).

NCAA.org, 'Women's 2007 Basketball Attendance', online at: http://fs.ncaa.org/Docs/ stats/w_basketball_RB/reports/Attend/07att.pdf (accessed December 1, 2011).

NCAA.org, '2007 Women's Softball RPI', online at: http://web1.ncaa.org/app_data/ weeklyrpi/2007WSBrpil.html (accessed December 1, 2011).

Office of Post-Secondary Education (2011), 'The Equity in Athletics Data Analysis Cutting Tool', online at: http://ope.ed.gov/athletics/ (accessed November 23, 2011).

Rhode, Deborah L. and Christopher J. Walker (2008), 'Gender Equity in College Athletics: Women Coaches as a Case Study', Stanford Journal of Civil Liberties, 4, February: 1-50.

Soccer America's College Soccer Reporter, 'Soccer America Women's Top 25: Final Rankings', online at: http://www.socceramerica.com/article/1614/5-soccer-americawomens-top-25-final-rankings.html (accessed December 1, 2011). 
Peter von Allmen - 9781849809399 Downloaded from PubFactory at 04/26/2023 02:12: 02PM via free access 